\title{
Effect of Balance Exercise on Risk of Falls among Institutionalized Elders
}

\author{
In Lattakia, Syria
}

\author{
Fatima Adnan Hallaj, Assistant Professor \\ Gerontological Nursing, Faculty of Nursing, Tishreen University-Syria
}

\begin{abstract}
Poor balance is a major risk factor for falls. Exercise which specifically improves balance is the most effective intervention for preventing falls. Objective: Determine the effect of balance exercise on risk of falls among institutionalized elderly in Lattakia, Syria. Setting: The study was carried out in the three available homes for elderly people in Lattakia, Syria. Subjects: The study subjects comprised 40 elderly persons. They were divided randomly into two equal groups: study and control. Each group comprised 20 elders where elders in the control group were left to their routine while those in the study group were subjected to balance exercise program for three months. Tools: Two tools were used for data collection: 1) the Tinetti Balance Assessment Tool and 2) the sociodemographic and clinical structure interview schedule. Results: The implemented exercise had a positive effect on risk of fall among elders where about a quarter showed no risk of falls and about a quarter showed improvements in their balance and gait status. Conclusion: The balance exercise succeeded in decreasing the risk of fall among elders. This improvement was significantly affected by the previous history of fall. Recommendations: Encourage elders to perform balance exercise in their daily routine to maintain balance and improve gait status and consequently prevent fall.
\end{abstract}

Keywords: Balance exercise; Risk of falls; Institutionalized elders.

\section{Introduction}

Incidence of falls has become a vital health care issue in geriatric research. Research efforts have been made to identify and prevent risks that cause falls and aggravate fall-related injuries, particularly within the health care institutions ${ }^{(1,2)}$. Significant morbidity, mortality, and costs among hospitalized patients were found to be highly associated with inward falls and after-fall injuries, and expectedly the rate of fall-related deaths rises rapidly with age ${ }^{(3,4)}$.

Over one-third of all people 65 years and older fall each year, and approximately $10 \%$ of all falls result in serious physical injuries, half of which are fractures ${ }^{(5)}$. Each year, United States hospitals have 300,000 admissions for broken hips, and falling is often the cause of those fractures ${ }^{(6)}$. According to the 2012 National Statistics in Taiwan about inpatient safety, falls comprised nearly one-fourth of all reported accidents within the health care institutions, and $42.5 \%$ were among patients aged 65 years and older ${ }^{(2)}$. In Egypt, a study carried out in elderly homes in Alexandria (2001) reported that more than one fifth of their residents suffered from falls ${ }^{(7)}$. Other studies in Alexandria and Ain Shams also reported that falls were the most common cause of fractures and admission to the hospital among elderly persons ${ }^{(8-11)}$.

The common consequences of fall among older people are fractures especially in the hips, anxiety, fear of falling, restriction of activity, disability, loss of independence, balance and strength impairments, recurrent fall, high morbidity, mortality and costs for the family and society. This, in turn will affect elders' quality of life ${ }^{(12,13)}$. The World Health Organization identifies a fall as one of the external cause of unintentional injury ${ }^{(13)}$. Moreover, fractures occur when institutionalized elders are faced with an environment that is notably different from that of their own homes, the absence of the family, loss of autonomy and physical inactivity all contribute to decline in 
functional capacity ensues, predisposing residents to falls, which often recur ${ }^{(2,14)}$.

Risks for fall are multifactorial, older adults fall as a result of interactions between intrinsic, demographical, pharmacologic, behavioral and environmental factors. The main risk factors for falls among this population are related to functional limitations, history of falls, increasing age, muscle weakness, environmental risks, visual deficits, alternation in vestibular function, cognitive decline, frequent toileting, disease and specific medications which cause dizziness, vertigo, and problems with walking ${ }^{(15,16)}$.

Aging affects the properties of the central nervous and neuromuscular systems, leading to problems with balance and walking. Balance is an important component of physical fitness that must be maintained in order to prevent falls. The systems responsible for postural stability are also affected, with reductions in responsiveness and compensation, resulting in increased instability $^{(4,17)}$.

The brain, muscles and bones, nerves and inner ear all work together to maintain the body's balance and keep individuals from falling. The systems model focuses on a dynamic interplay among various systems by integrating both motor and sensory strategies to maintain static and dynamic balance. This integration is a complex process that depends on sensory inputs, sensorimotor integration by the central nervous system, and postural responses. Balance includes biomechanical factors, sensory organization, and coordination of postural movements (musculoskeletal components) ${ }^{(17,18)}$.

Balance is essential for individuals to move about their environment and successfully carry out daily activities ${ }^{(19)}$. Good balance is important to maintain older adults living independently, productively, and proactively in housework, cooking, shopping, and traveling. Maintenance of a balanced independence is essential for staying healthy and for wellbeing. Poor balance is a major risk factor for falls, a leading cause of hospitalization and nursing home requirements ${ }^{(19-21)}$.

Fall prevention involves managing a patient's intrinsic risk factors and develops preventive strategies aimed at improving functional capacity, maintaining the wellbeing of elders, and reduce care costs ${ }^{(15,16)}$. The effectiveness of balance exercise in reducing the risk of falls has been addressed in previous studies ${ }^{(21,22)}$. Balance exercises can help an older adult to avoid falling by improving his ability to control and maintain his body's position, whether he is moving or still. It is safe, effective, and acceptable to older adults and healthcare provider. In addition, balance exercises promote increased muscle strength, aerobic conditioning, flexibility and balance, and reduce the risk of falls and consequently improve quality of life ${ }^{(18,23)}$. A number of recommendations suggest that to get benefit elders should perform balance exercise three times a week for twelve weeks ${ }^{(24,25)}$.

The balance exercises for falls prevention include heel to toe standing/walking this helps to keep balance when the elders have to walk through a narrow space, raising knee helps with climbing stairs and getting in and out of cars and buses. Side leg raise/sideways walking improves stability when the elders have to take weight on one leg and helps him step sideways to avoid tripping. Heel raise helps with walking and climbing stairs, stepping up a step which improves stability on steps, paths and uneven surfaces. Sit to stand helps with getting up and down from a chair or toilet and in and out of the $\mathrm{car}^{(18)}$.

The gerontological nurse plays an important role in motivating elders for a more active life style through performing a various type of exercises. As well, she should stress the importance of practicing the balance exercise in order to prevent or reduce falls ${ }^{(20,23)}$. 
Although a normal sense of balance to prevent falls becomes vital, no adequate attention is given in this respect in Syria. This study needs to draw additional document on balance exercise as an effective technique for fall prevention among elderly population.

\section{Aim of the Study}

The aim of this study is to determine the effect of balance exercise on risk of falls among institutionalized elderly in Lattakia, Syria.

\section{Research Hypothesis}

The application of balance exercise will reduce the risk of falls among institutionalized elderly.

\section{Materials and Method}

\section{Materials}

Design: Quasi experimental research design.

Setting: The study was carried out in the three available residential homes for elderly people in Lattakia, Syria. These were Dar Al Raha, Dar Al Mowasat, and Dar Al Ber.

1- Dar Al Raha: accepts both male and female elders. The total number of residents that it can accommodate is 48 elders.

2- Dar Al Mowasat: accepts only female elders and can accommodate up to 52elders.

3- Dar El Ber: accepts only male elders and can accommodate up to 46 elders.

Subjects: The study subjects amounted to 40 elderly of both genders residing in the previous settings and fulfilling the following criteria: age 60 years and more, at risk of falls (score less than 28), able to move without assistance, mentally capable of understanding and performing the balance exercise, no acute disease state, and agree to participate in the study. The systematic random sampling technique was used to select the sample from those fulfilling the inclusion criteria.

Tools: Two tools were used to collect the data:
Tool I: The Tinetti Balance Assessment Tool

It was developed by Tinetti ME et al. $(1986)^{(26)}$. It is used to identify risk of falls among elderly people. It consists of 2 parts: the balance section and the gait section. The balance section includes items that assess elderly balance while sitting, rising from chair, attempts to rise, immediate standing balance, standing balance, turning 360 degrees, and sitting down. The second gait section includes items that assess elderly gait: indication of gait, step length and height, foot clearance, step symmetry, step continuity, path, trunk, and walking time.

The maximum score is 28 , and is obtained through assessing elder's balance during each item from these activities. The total score categories is evaluated according to the score obtained in the following manner:

Tinetti tool score

$\begin{array}{cc}\leq 18 & \text { High } \\ 19-23 & \text { Moderate } \\ \geq 24 & \text { Low } \\ 28 & \text { No }\end{array}$

\section{Tool II: Socio-demographic and Clinical} Data Structured Interview Schedule

It was designed by the researcher after thorough review of literature and included the following data:

1- Data about the elders': Socio demographic characteristics such as age, gender, social status, level of education, duration of stay in the home.

2- Clinical data: presence of chronic diseases and physical conditions that might affect balance status such as pain, fear, medication used.

\section{Method}

\section{- Development of the Program:}

This was developed by the researcher after thorough review of literature. The elders practice the balance exercise 3 sessions per week for 3 
months. The duration of each session was about 45 minutes.

- Official approvals from the competent authorities to carry out the study were obtained.

- The study tools were validated by five experts in the field of the study. Arabic translation of tool I (The Tinetti Balance Assessment tool) was done by the researcher, validated and tested for its reliability using test retest method (after 2 weeks). It was applied to 20 elders. Spearman's correlation coefficient for tool I was $\mathrm{r}=0.92$.

- Informed consent from elders to participate in the study was obtained after explanation of the study purpose.

- A pilot study was conducted on five elders selected from Dar Al Raha to test the study tools. The necessary modifications were made based on the results of the pilot study. These elders were excluded from the study sample.

- Survey to all residents (146 elders) in the three homes was done in order to identify those fulfilling the study criteria. Their number amounted to 61 elders, of them 7 refused to participate in the study and from the rest the researcher selected 40 elders using the systematic random sample technique.

- The selected elders were assigned to two equal groups of 20 elders each (the study and control groups). Elders in the control group were left to their routine pattern while those in the study group were divided into four sub-groups. Each sub-group consisted of 3- 8 elders.

- Because of elders' resistance and worry about performing any physical exercise; probably due to the sedentary life they assumed for long period in the residential homes, the researcher had to explain and demonstrate the different exercises to be performed during the study period. Also, illustrative video showing elderly people while practicing the balance exercise helped to encourage the elders to participate in the program. This required 8 sessions prior the actual implementation of the exercise program in order to alleviate elders' fear and motivate them to accept to participate in the study.

\section{- Program implementation:}

- The researcher greeted the elders, introduced herself, gave a brief summary about the benefits and components of the exercise program and asked the elders to cooperate for their benefits.

- Before the start of the program, the researcher explained the precautions to be undertaken by the elders during performing the balance exercise to ensure and maintain the elders' safety. This included stopping immediately in case he feels muscle cramps or a side "stitch", or dizziness or excessive shortness of breath or fatigue. Also, she emphasized the importance of starting the exercise slowly and increase gradually according to each elder tolerance. Also, the importance to begin with warm up for 10 minutes and end with cool down for 5 minutes.

- During each of the program sessions the researcher demonstrated only one type of exercise and presented a video showing elderly persons while practicing these exercises. This helped to encourage the elderly persons to share in the activity. Then each elder was asked to perform the demonstrated exercise under the researcher supervision for their safety, security and to foster elder's confidence. Right practice was praised and wrong 
practice was corrected. Beside small presents were given to participants after each session in order to encourage them to complete the program.

- The balance exercises program was implemented in groups for all elders in the study group for three sessions (one session per day) on three days per week and repeated for three months (total: 36 sessions). These sessions were implemented in the morning and lasted for 45 minutes per session. The elders performed the following exercises:
- Start by warm up for 10 minutes this includes: flexibility exercises performed in sitting and standing positions.

- Balance exercise (done for 30 minutes) while walking, then while standing. This was performed by the elder 5- 10 times each, as following:

1- Heel-to-toe standing/walking: This helps to keep balance when the elders
have to walk through a narrow space
2- Knee raises: Helps with climbing stairs and getting in and out of cars and
buses
3- Side leg raise/sideways walking: Improves stability when the
elders have to take weight on one leg and helps to step sideways
to avoid tripping




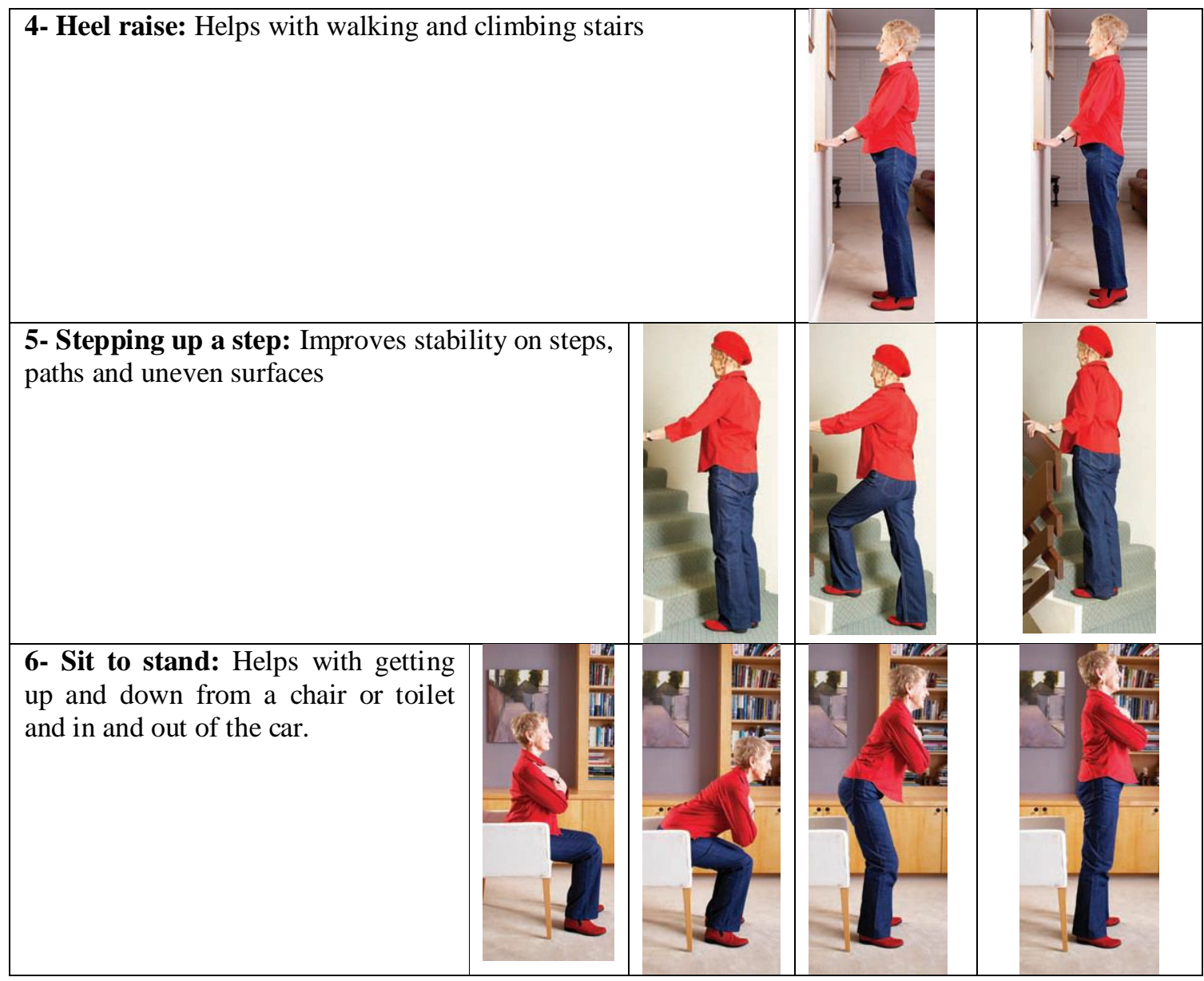

- Cool down for 5 minutes: This included relaxation activities of the upper and lower limbs.

\section{- Evaluation of the program:}

After the implementation of the balance exercises for three months, each of the participants in the two groups was reassessed to evaluate his risk of falls using tool I "Tinetti Balance Assessment Tool".

- Data collection started from the first of May 2018 to the end of October 2018.

\section{Ethical considerations:}

Privacy and confidentiality of the collected data was assured. Each elderly was informed about his right to withdraw from the study without penalties.

\section{Statistical Analysis}

- All analyses were completed using the Statistical Package for the Social Sciences (SPSS) version 18 (IBM Corporation).

- Descriptive statistics using means (standard deviations) for continuous data and frequencies (\%) for categorical data were calculated.

- The chi-square and Fisher's exact tests were used to compare percentages between groups.

- The $\mathrm{t}$ test was used to compare differences between continuous variables.

\section{Results}

The 40 elders who participated in the study were 10 (25.0\%) from Dar Al Ber, 14 
(35.0\%) from Dar Al Mowasat and 16 (40.0\%) from Dar Al Raha.

Table (1) shows the socio-demographic characteristics of the elders. No significant difference was found between the study and control groups with respect to sociodemographic characteristics. The age of the elders ranged from 63 to 82 years. The mean age of the study and control groups was $73.0 \pm 45.6$ years and $73.2 \pm 4.5$ years respectively. More than half $(55.0 \%)$ in each of the two groups were females. Two thirds $(60.0 \%)$ in each of the two groups had up to preparatory level of education, $30.0 \%$ and $35.0 \%$ of the study and control groups respectively had secondary school education, and the rest had higher education (10.0\% and $5.0 \%$ for the study and control groups respectively). The same percent $(35.0 \%)$ of the study and control groups were housewife, and employee constituted $35.0 \%$ and $40.0 \%$ of the study and control groups respectively. As for the duration of stay in the home $35.0 \%$ and $40.0 \%$ of the study and control groups reported being in the home for less than 5 years, for those admitted 5 to less than 10 years were $35.0 \%$ and $45.0 \%$ respectively for the study and control groups, and only $(30.0 \%, 15.0 \%)$ of the study and control groups respectively reported being for 10 years or more.

Table (2) shows the health profile of elders in the two groups. No significant difference was found between the study and control groups with respect to their health profile. It appears from the table that $(20.0 \%, 15.0 \%)$ of the study and control groups respectively reported having no chronic diseases, while the rest in both groups reported cardiovascular disorders (30.0\% and $25.0 \%$ respectively); musculoskeletal disorders $(25.0 \%$ and $20.0 \%$ respectively); GIT disorders $(15.0 \%$ and $20.0 \%$ respectively); metabolic disorders as DM (10.0\% and $15.0 \%$ respectively); and nerves disorders $(5.0 \%$ and $5.0 \%$ respectively). The table also shows that $25.0 \%$ in the study group and $15.0 \%$ in the control group did not take any medication, while the rest in both groups reported taking anti-hypertensive $(30.0 \%$ and $25.0 \%$ respectively); diuretic (25.0\% and $35.0 \%$ respectively); analgesics $(20.0 \%$ and $20.0 \%$ respectively); digoxin (15.0\% and $10.0 \%$ respectively); hypoglycemic (10.0\% and $15.0 \%$ respectively); and antacid (15.0\% and $10.0 \%$ respectively).

Table (3) shows the mean score of the Tinetti balance assessment tool of the elders in both groups before and after 3 months. Applying the Tinetti balance assessment tool on both groups before and three months after the implementation of the balance exercise the table shows improvement in the mean score, i.e., it increased from 19.5 to 21 in the study group while in the control group it became worse , i.e., it decreased from 19.9 to 18 . The difference between the mean change in the two groups is statistically significant $(\mathrm{P}=0.0001)$.

Table (4) applying the Tinetti balance assessment tool on the study group before and after three months from the implementation of balance exercise program the table shows that all elders with low risk of falls before the implementation of the balance exercise had no risk after the program and $44.45 \%$ of those with moderate risk of falls showed improvement in their balance and gait after the program where they had low risk of falls, and $25.0 \%$ of those with high risk of falls turned to the moderate risk after the program. These differences are statistically significant $(\mathrm{P}=0.0001)$.

Table (5) applying the Tinetti balance assessment tool on the control group immediately after selection and three months later the table shows no improvement in their balance and gait. On the contrary, the condition became worse among many of them. Among the 7 elders with low risk of falls one became worse after three months; it turned to have moderate risk of falls. Also, two of the $8(25.0 \%)$ of elders with moderate risk of falls changed to the high risk of falls after three months and all those with high risk of falls continued to be so. These 
differences are statistically significant $(\mathrm{P}=0.0001)$.

Table (6) shows the relation between elders' characteristics among the study group and the mean change in the risk of fall before and 3 months after the implementation of the program. The improvement in the balance and gait among elders who performed the balance exercise was significantly associated only with the elders' previous history of falls $(\mathrm{P}=0.0002)$. While no statistical significant difference was observed between the characteristics of the study subjects (age, sex, duration of stay in the home and presence of chronic diseases) and the mean change in the risk of fall after implementation of the program.

\section{Discussion}

Prevention of falls is considered of public importance as more than one third of people aged 65 and over fall each year. Falls usually lead to injuries, decreased functional capacity and death. Balance exercise represents a key strategy for the prevention of falls among institutionalized elderly ${ }^{(17,27)}$. Therefore, the study aimed to determine the effect of balance exercises on the risk of falls among institutionalized elderly in Lattakia, Syria.

The study findings revealed a significant improvement in the balance and gait status of elders in the study group after practicing the balance exercises for three months where half of them showed marked improvement in their balance and gait (Table 4). This is due to their regular practice of the balance exercise during the study period which succeeded in improving their condition. On the other hand, elders in the control group continued to be at risk of fall after the study period (Tables 3, 4 and 5). It was also noted that elders who practiced the balance exercise were found to perform easily the different activities of daily living. Also they were able to sit down and stand up safely from chair without help. As well, their balance ability improved greatly when standing where their stand balance was steady without using walker or other support. Also, they were more able to be steady when nudged and remained standing without support even with eyes closed. Moreover, they mastered turning 360 degrees steadily. Also, their walking became better without sway or flex and without using the arms or walking aids. As well, they became more able to step continuously with equal length, height, and clearance for right and left step with narrow stance without support. This indicates that elders with better capacity for the maintenance of balance performed better in functional tasks and consequently had a lower risk of falls. This improvement may be attributed to the effect of the balance exercises which improved functioning of stabilizing muscles where it strengthens the muscles and improves joint function improving upper, lower, and core body strength, endurance, flexibility, and coordination of the limbs and trunk which in turn improved balance and decreased risk for falls or injury related to poor balance. This supports the findings of other studies $^{(21,28,29)}$.

Among the study group a significant improvement in balance and a reduction in the estimated risk of falls was noted when compared with the control group. As all elders in the study group, with low risk of falls before the implementation of balance exercise had no risk after the program implementation and nearly half of those with moderate risk of falls showed improvement in their balance and gait after the program where they became at low risk of falls and only $25.0 \%$ of those with high risk of falls turned to the moderate risk after the program (Table 4). While in the control group no improvement was observed; on the contrary, they showed reduction in body balance and were at increased risk of falls and for five of them the condition became worse after the three months of the study (Table 5).

One can notice that the practice of balance exercise decreases the risk of fall by preventing the condition from getting worse. This probably may be due to the fact that 
balance exercise improves significantly the power and strength of leg muscle especially those at the knee and ankle which in turn develops a greater sense of control on gait stability and master maintenance of balance. As for those with high risk of falls, they may require longer period of practice balance exercise. The same findings were reported in other studies ${ }^{(30-32)}$.

Findings of the present study indicate that the history of fall had a significant relation with the risk of falls after performing the balance exercise sessions (Table 6). The less the number of falls the better the results because the fear from fall and falls itself has adverse effects on the balance and gait status. This is because fall may result in trauma, fracture and dependency which leads elders to have less control over their environment especially for those who are not using the required assistive devices. Thus, the risk of falls usually worsens with the increase in the number of falls and this may need a longer period of exercise to be effective. The same findings were reported in another study ${ }^{(33)}$.

Conversely, gender, age, duration of stay in the home, and presence of diseases have no significant relation with the risk of falls after performing the balance exercise sessions (Table 6). This can be explained by the fact that all elders from both genders share the same risk factors conductive to falls. In addition to the small number of subjects included in the study. Plus the fact that elders enrolled in the study had no chronic degenerative diseases that may cause fall. This supports the findings of another study ${ }^{(34)}$, while contradicts another study carried out in Japanese $(2004)^{(35)}$ where higher figures of falls were reported among elderly women.

However, there is a general consensus that balance exercise is a powerful intervention to obtain long-term benefits on muscle function, reduce the frequency of falls, maintains independence, ultimately improves function, and a high quality of life in elders ${ }^{(36)}$.This was also observed from the results of the present study.

\section{Conclusion}

It can be concluded from the study that the balance exercises was effective in increasing balance and gait status and particularly in reducing the estimated risk of falls among institutionalized elderly persons.

\section{Recommendations}

- Assessment of elders residing in elderly homes is required to detect early those at risk of fall in order to plan and implement early balance exercise to strengthen muscle function, reduce the risk of falls and maintain independence.

- Balance exercise should be part of the daily routine of elders residing in elderly homes.

- Caregivers should be taught about the importance, technique and benefits of the balance exercise to be able to teach, encourage and motivate the elders to regularly perform the exercise under their supervision.

\section{Limitations}

- Three elders refused to join in the exercise sessions, believing that it is of no benefit and dangerous.

- Two elders withdrew from the exercise sessions and refused to complete the sessions. These were replaced by other residents to maintain the sample size. 
Table (1): Distribution of elders in the study and control groups according to their sociodemographic characteristics

\begin{tabular}{|c|c|c|c|c|c|}
\hline \multirow{2}{*}{ Socio-demographic Characteristics } & \multicolumn{2}{|c|}{ Study group } & \multicolumn{2}{|c|}{ Control group } & \multirow[b]{2}{*}{ Significant } \\
\hline & $\begin{array}{l}\text { NO. } \\
\mathrm{n}=\mathbf{2 0}\end{array}$ & $\begin{array}{c}\% \\
100\end{array}$ & $\begin{array}{l}\text { NO. } \\
\mathrm{n}=\mathbf{2 0}\end{array}$ & $\begin{array}{c}\% \\
100\end{array}$ & \\
\hline \multicolumn{6}{|l|}{ Age (in years): } \\
\hline - $60-$ & 6 & 30.0 & 5 & 25.0 & \multirow{4}{*}{$\mathrm{P}=0.937$} \\
\hline - $70-$ & 12 & 60.0 & 13 & 65.0 & \\
\hline - $\quad \geq 80$ & 2 & 10.0 & 2 & 10.0 & \\
\hline Mean \pm SD & \multicolumn{2}{|c|}{$73 \pm 5.6$} & \multicolumn{2}{|c|}{$73.2 \pm 4.5$} & \\
\hline \multicolumn{6}{|l|}{ Sex: } \\
\hline - Female & 11 & 55.0 & 11 & 55.0 & $\mathrm{P}=1$ \\
\hline - Male & 9 & 45.0 & 9 & 45.0 & \\
\hline \multicolumn{6}{|l|}{ Marital status: } \\
\hline - Widowed & 15 & 75.0 & 16 & 80.0 & \\
\hline - Single & 2 & 10.0 & 2 & 10.0 & $\mathrm{P}=0.89$ \\
\hline - Divorced & 3 & 15.0 & 2 & 10.0 & \\
\hline \multicolumn{6}{|l|}{ Educational Level: } \\
\hline - Up to preparatory & 12 & 60.0 & 12 & 60.0 & \\
\hline - Secondary & 6 & 30.0 & 7 & 35.0 & $\mathrm{P}=0.815$ \\
\hline - Higher education & 2 & 10.0 & 1 & 5.0 & \\
\hline \multicolumn{6}{|l|}{ Occupation before retirement: } \\
\hline - Housewife & 7 & 35.0 & 7 & 35.0 & \\
\hline - Employee & 7 & 35.0 & 8 & 40.0 & $\mathrm{P}=0.976$ \\
\hline - Technical worker & 4 & 20.0 & 3 & 15.0 & \\
\hline - Business & 2 & 10.0 & 2 & 10.0 & \\
\hline \multicolumn{6}{|l|}{$\begin{array}{l}\text { Duration of stay in the home (in } \\
\text { years) }\end{array}$} \\
\hline - 1 - & 7 & 35.0 & 8 & 40.0 & \\
\hline - $5-$ & 7 & 35.0 & 9 & 45.0 & $\mathrm{P}=0.518$ \\
\hline - $\geq 10$ & 6 & 30.0 & 3 & 15.0 & \\
\hline
\end{tabular}

* Significant $P \leq 0.05$ 
Table (2): Distribution of elders in the study and control groups according to their health profile

\begin{tabular}{|c|c|c|c|c|c|}
\hline \multirow{2}{*}{ Health Profile } & \multicolumn{2}{|c|}{ Study group } & \multicolumn{2}{|c|}{ Control group } & \multirow{2}{*}{$\begin{array}{c}\text { Test of } \\
\text { Significance }\end{array}$} \\
\hline & $\begin{array}{c}\text { NO. } \\
\mathbf{n}=\mathbf{2 0}\end{array}$ & $\begin{array}{c}\% \\
100\end{array}$ & $\begin{array}{l}\text { NO. } \\
\mathrm{n}=\mathbf{2 0}\end{array}$ & $\begin{array}{c}\% \\
100\end{array}$ & \\
\hline $\begin{array}{l}\text { Vision disorders: } \\
\text { - No } \\
\text { - Yes }\end{array}$ & $\begin{array}{c}14 \\
6\end{array}$ & $\begin{array}{l}70.0 \\
30.0\end{array}$ & $\begin{array}{c}12 \\
8\end{array}$ & $\begin{array}{l}60.0 \\
40.0\end{array}$ & $P=0.507$ \\
\hline $\begin{array}{l}\text { Hearing disorders: } \\
\text { - No } \\
\text { - Yes }\end{array}$ & $\begin{array}{c}11 \\
9\end{array}$ & $\begin{array}{l}55.0 \\
45.0\end{array}$ & $\begin{array}{c}11 \\
9\end{array}$ & $\begin{array}{l}55.0 \\
45.0\end{array}$ & $\mathrm{P}=1$ \\
\hline $\begin{array}{l}\text { Diseases: \# } \\
\text { - None } \\
\text { - Cardiovascular disorders } \\
\text { - Musculoskeletal disorders } \\
\text { - } \text { GIT disorders } \\
\text { - Metabolic disorders (DM) } \\
\text { - Nerves disorders } \\
\text { - Respiratory disorders } \\
\text { - Urinary disorders }\end{array}$ & $\begin{array}{l}4 \\
6 \\
5 \\
3 \\
2 \\
1 \\
0 \\
1\end{array}$ & $\begin{array}{c}20.0 \\
30.0 \\
25.0 \\
15.0 \\
10.0 \\
5.0 \\
0.0 \\
5.0\end{array}$ & $\begin{array}{l}3 \\
5 \\
4 \\
4 \\
3 \\
1 \\
1 \\
0\end{array}$ & $\begin{array}{c}15.0 \\
25.0 \\
20.0 \\
20.0 \\
15.0 \\
5.0 \\
5.0 \\
0.0\end{array}$ & $\begin{array}{c}\mathrm{P}=0.677 \\
\mathrm{P}=0.723 \\
\mathrm{P}=0.49 \\
\mathrm{P}=0.548 \\
\mathrm{P}=0.736 \\
\mathrm{P}=1 \\
\mathrm{P}=1 \\
\mathrm{P}=1\end{array}$ \\
\hline $\begin{array}{l}\text { Drugs: \# } \\
\text { - None } \\
\text { - Anti-hypertensive } \\
\text { - Diuretic } \\
\text { - Anti-inflammatory and analgesics } \\
\text { - Digoxin } \\
\text { - Anpoglycemic } \\
\text { - Antacid } \\
\text { - Bronchodic } \\
\end{array}$ & $\begin{array}{l}5 \\
6 \\
5 \\
4 \\
3 \\
2 \\
3 \\
2 \\
1\end{array}$ & $\begin{array}{l}25.0 \\
30.0 \\
25.0 \\
20.0 \\
15.0 \\
10.0 \\
15.0 \\
10.0 \\
5.0\end{array}$ & $\begin{array}{l}3 \\
5 \\
7 \\
4 \\
2 \\
3 \\
2 \\
1 \\
0\end{array}$ & $\begin{array}{l}15.0 \\
25.0 \\
35.0 \\
20.0 \\
10.0 \\
15.0 \\
10.0 \\
5.0 \\
0.0\end{array}$ & $\begin{array}{c}\mathrm{P}=0.429 \\
\mathrm{P}=0.723 \\
\mathrm{P}=0.49 \\
\mathrm{P}=1 \\
\mathrm{P}=1 \\
\mathrm{P}=0.677 \\
\mathrm{P}=0.677 \\
\mathrm{P}=0.733 \\
\mathrm{P}=0.548\end{array}$ \\
\hline $\begin{array}{l}\text { History of falls: } \\
\qquad \quad \text { No } \\
\qquad \quad \text { Yes }\end{array}$ & $\begin{array}{c}11 \\
9\end{array}$ & $\begin{array}{l}55.0 \\
45.0\end{array}$ & $\begin{array}{c}12 \\
8\end{array}$ & $\begin{array}{l}60.0 \\
40.0\end{array}$ & $\begin{array}{l}\mathrm{P}=0.987 \\
\mathrm{P}=0.823\end{array}$ \\
\hline
\end{tabular}

* Significant $P \leq 0.05$

\# More than one answer 
Table (3): Table: Mean score of Tinetti balance assessment tool of elders in both groups before and after three months from the implementation of the balance exercise

\begin{tabular}{||l|c|c|c||}
\hline \multirow{2}{*}{$\begin{array}{l}\text { Mean score Tinetti balance assessment } \\
\text { tool (total score 28) }\end{array}$} & $\begin{array}{c}\text { Study group } \\
\mathbf{n = 2 0}\end{array}$ & $\begin{array}{c}\text { Control group } \\
\mathbf{n = 2 0}\end{array}$ & \multirow{2}{*}{ P value } \\
\cline { 2 - 3 } & Mean \pm SD & Mean \pm SD & \\
\hline - Before & $19.5 \pm 4.1$ & $19.9 \pm 4.3$ & $\mathrm{P}=0.7657$ \\
- After 3 months & $21 \pm 5.4$ & $18 \pm 5.7$ & $\mathrm{P}=0.0907$ \\
\hline Mean change \pm SD & $1.5 \pm 1.7$ & $-1.9 \pm 1.9$ & $\mathrm{P}=0.0001^{*}$ \\
\hline \multicolumn{1}{|c|}{ P value } & $\mathrm{P}=0.001^{*}$ & $\mathrm{P}=0.0002^{*}$ & \\
\hline
\end{tabular}

* Significant $P \leq 0.05$

Table (4): Distribution of elders in the study group according to the risk of falls before and 3 months after the implementation of the balance exercise

\begin{tabular}{|c|c|c|c|c|c|c|c|c|c|c|c|}
\hline \multirow{3}{*}{\multicolumn{3}{|c|}{$\begin{array}{l}\text { Risk of falls using Tinetti } \\
\text { balance assessment tool }\end{array}$}} & \multicolumn{8}{|c|}{$\begin{array}{l}\text { Risk of falls after } 3 \text { months } \\
(\text { n.=20) }\end{array}$} & \multirow[t]{3}{*}{$P$ value } \\
\hline & & & \multicolumn{2}{|c|}{ No } & \multicolumn{2}{|c|}{ Low } & \multicolumn{2}{|c|}{ Moderate } & \multicolumn{2}{|c|}{ High } & \\
\hline & & & No. & $\%$ & No. & $\%$ & No & $\%$ & No. & $\%$ & \\
\hline \multirow{3}{*}{$\begin{array}{c}\text { Risk of } \\
\text { falls } \\
\text { before }\end{array}$} & $\begin{array}{l}\text { Low } \\
\geq 24 \\
\end{array}$ & $\begin{array}{l}\text { No. } \\
\mathrm{n}=7\end{array}$ & 7 & 100.0 & & & & & & & \multirow[t]{3}{*}{$\mathrm{P}=0.0001^{*}$} \\
\hline & $\begin{array}{l}\text { Moderate } \\
19-25\end{array}$ & $\begin{array}{l}\text { No. } \\
\mathrm{n}=9\end{array}$ & & & 4 & 44.45 & 5 & 55.55 & & & \\
\hline & $\begin{array}{l}\text { High } \\
\leq 18 \\
\end{array}$ & $\begin{array}{l}\text { No. } \\
\mathrm{n}=4\end{array}$ & & & & & 1 & 25.0 & 3 & 75.0 & \\
\hline
\end{tabular}

* Significant $P \leq 0.05$ 
Table (5): Distribution of elders in the control group according to the risk of falls before and 3 months after the implementation of the balance exercise

\begin{tabular}{|c|c|c|c|c|c|c|c|c|c|}
\hline \multirow{3}{*}{\multicolumn{3}{|c|}{$\begin{array}{l}\text { Risk of falls using Tinetti } \\
\text { balance assessment tool }\end{array}$}} & \multicolumn{6}{|c|}{ Risk of falls after 3 months } & \multirow{3}{*}{$P$ value } \\
\hline & & & \multicolumn{2}{|c|}{ Low } & \multicolumn{2}{|c|}{ Moderate } & \multicolumn{2}{|c|}{ High } & \\
\hline & & & No. & $\%$ & No. & $\%$ & No. & $\%$ & \\
\hline \multirow{3}{*}{$\begin{array}{l}\text { Risk of } \\
\text { falls before }\end{array}$} & $\begin{array}{l}\text { Low } \\
\geq 24\end{array}$ & $\begin{array}{l}\text { No. } \\
n=7\end{array}$ & 6 & 85.71 & 1 & 14.29 & & & \multirow[t]{3}{*}{$\mathrm{P}=0.0001 *$} \\
\hline & $\begin{array}{l}\text { Moderate } \\
19-25 \\
\end{array}$ & $\begin{array}{l}\text { No. } \\
\mathrm{n}=8\end{array}$ & & & 6 & 75.0 & 2 & 25.0 & \\
\hline & $\begin{array}{l}\text { High } \\
\leq 18\end{array}$ & $\begin{array}{l}\text { No. } \\
n=5\end{array}$ & & & & & 5 & 100.0 & \\
\hline
\end{tabular}

* Significant $P \leq 0.05$

Table (6): Relation between elders' characteristics of the study subjects and the mean change in the risk of fall before and 3 months after the implementation of the program

\begin{tabular}{|c|c|c|c|c|}
\hline \multirow{3}{*}{ Elders' characteristics } & \multicolumn{3}{|c|}{ Study group } & \multirow{3}{*}{$P$ value } \\
\hline & Before & After & \multirow{2}{*}{$\begin{array}{l}\text { Mean change } \\
\quad \pm \text { SD }\end{array}$} & \\
\hline & $\begin{array}{c}\text { Mean score } \pm \\
\text { SD }\end{array}$ & $\begin{array}{c}\text { Mean score } \pm \\
\text { SD }\end{array}$ & & \\
\hline $\begin{array}{ll}\text { Sex: } & \\
\text { - } & \text { Female } \\
\text { - } & \text { Male }\end{array}$ & $\begin{array}{c}19.7 \pm 4.9 \\
19.2 \pm 3\end{array}$ & $\begin{array}{l}21 \pm 6.2 \\
21 \pm 4.6\end{array}$ & $\begin{array}{c}1.3 \pm 1.6 \\
1.8 \pm 2\end{array}$ & $\mathrm{P}=0.5312$ \\
\hline $\begin{array}{c}\text { Age in years: } \\
\qquad \quad<75 \\
\cdot \quad \geq 75 \\
\end{array}$ & $\begin{array}{c}20.7 \pm 4.7 \\
18 \pm 2.8\end{array}$ & $\begin{array}{c}22.8 \pm 6 \\
18.8 \pm 3.9 \\
\end{array}$ & $\begin{array}{l}2.1 \pm 1.7 \\
0.8 \pm 1.6\end{array}$ & $\mathrm{P}=0.0726$ \\
\hline $\begin{array}{l}\text { Duration of } \text { stay in the } \\
\text { home: } \\
\qquad \quad<5 \text { years } \\
\cdot \quad \geq 5 \text { years }\end{array}$ & $\begin{array}{l}20.8 \pm 5.1 \\
18.5 \pm 2.9\end{array}$ & $\begin{array}{l}22.8 \pm 6.2 \\
19.5 \pm 4.5\end{array}$ & $\begin{array}{c}2 \pm 1.4 \\
1.1 \pm 1.9\end{array}$ & $\mathrm{P}=0.1533$ \\
\hline $\begin{array}{l}\text { Presence of diseases: } \\
\text { - Yes } \\
\text { - No } \\
\end{array}$ & $\begin{array}{l}19.9 \pm 4.1 \\
18.7 \pm 4.2\end{array}$ & $\begin{array}{l}21.8 \pm 5.5 \\
19.2 \pm 5.2\end{array}$ & $\begin{array}{l}1.9 \pm 1.8 \\
0.5 \pm 1.2\end{array}$ & $\mathrm{P}=0.0764$ \\
\hline $\begin{array}{c}\text { History of falls: } \\
\qquad \quad \text { Yes } \\
\bullet \quad \text { No }\end{array}$ & $\begin{array}{c}22 \pm 3.1 \\
16.4 \pm 2.9\end{array}$ & $\begin{array}{c}24.7 \pm 4 \\
16.4 \pm 2.9\end{array}$ & $\begin{array}{c}2.7 \pm 1.4 \\
0\end{array}$ & $\mathrm{P}=0.0002^{*}$ \\
\hline
\end{tabular}

* Significant $P \leq 0.05$ 


\section{References}

1. Hu Y, Chung Y, Yu H, Chen Y, Tasi C, Hu G. Effect of Tai Chi Exercise on fall prevention in older adults: systematic review and meta-analysis of randomized controlled trials. International Journal of Gerontology 2016; 10 (2016): 131- 6.

2. Li I, Hsiung $\mathrm{Y}$, Hsing $\mathrm{H}$, Lee $\mathrm{M}$, Chang T, Huang M. Elderly Taiwanese's intrinsic risk factors for fall-related injuries. International Journal of Gerontology 2016; 10 (2016): 137- 41.

3. Kim E, Arai H, Chan P, Chen L, Hill $\mathrm{K}$, Kong B, Poi P, Tan M, Yoo H, Won C. Strategies on fall prevention for older people living in the community: a report from a roundtable meeting in IAGG 2013. Journal of Clinical Gerontology \& Geriatrics 2015; 6 (2015): 39- 44.

4. Skelton D, Dinan S. Falls and fractures: exercise training to prevent falls. Glasgow Caledonian University Department of Health; 2009, 3- 8.

5. Arkkukangas M, Johnson S, Hellström K, Söderlund A, Eriksson S, Johansson A. A feasibility study of a randomized controlled trial comparing fall prevention using exercise with or without the support of motivational interviewing. Preventive Medicine Reports 2015, 2 (2015): 134- 40.

6. Alikhajeh Y, Hosseini S, Moghaddam A. Effects of hydrotherapy in static and dynamic balance among elderly men. Procedia - Social and Behavioral Sciences 2012; 46 (2012): $2220-4$.

7. El-Gameel M. Study of falls among institutionalized elderly in Alexandria. Thesis, MSc. Alexandria University, Faculty of Nursing, 2001; 68.
8. Teleb N. Accidents among elderly people attending the emergency department of the University Hospitals in Alexandria. MSc Thesis, Alexandria University, Faculty of Medicine, 1996.

9. El-Megid L. A study of the elderly's injuries in governmental hospitals in Alexandria. Tanta Med J 1994; 22 (1): 2045- 60 .

10. El-Noamany M. Geriatric fractures, risk factors: a literature review and a survey in hospital population of fractured elderly. MSc Thesis, Ain Shams: Ain Shams University, Faculty of Medicine, 1996.

11. Arafa H. Risk factors leading to proximal femur fractures among elderly patients. MSc Thesis, Alexandria University, Faculty of Nursing, 2001.

12. Noohu M, Dey A, Hussain M. Relevance of balance measurement tools and balance training for fall prevention in older adults. Journal of Clinical Gerontology \& Geriatrics 2014; 5 (2014): 31 - 5

13. Al-Faisal W. Falls prevention for older persons. Eastern Mediterranean Regional Review. Geneva: World Health Organization; 2006.

14. DeSure A, Peterson K, Gianan F, Pang L. An exercise program to prevent falls in institutionalized elderly with cognitive deficits: a crossover pilot study. Hawai'i Journal of Medicine \& Public Health 2013; 72 (11): 391- 5 .

15. Cockayne S, Rodgers S, Green L, Fairhurst C, Adamson J, Scantlebury A, Corbacho B, Hewitt CE, Hicks K, Hull R, Keenan AM, Lamb SE, Mclntosh C, Menz HB, Redmond A, 
Richardson Z, Vernon W, Watson J, Torgerson DJ. Clinical effectiveness and cost-effectiveness of a multifaceted podiatry intervention for falls prevention in older people: a multicenter cohort randomized controlled trail (the reducing falls with orthoses and a multifaceted podiatry intervention trial). Health Technol Assess 2017; 21 (24): 1- 19.

16. Chen P. Elderly falls in hospitals. International Journal of Gerontology 2016; 10 (2016): 125-9.

17. Martin J, Wolf A, Moore J, Rolenz E, DiNinno A, Reneker J. The effectiveness of physical therapistadministered group-based exercise on fall prevention: a systematic review of randomized controlled trails. J Geriatr Phys Ther 2013; 36 (4): 182- 93.

18. Australia Ministry of Health. Staying active and on your feet: Falls prevention program. Australia: NSW Ministry of Health, 2013; 4-5. Available at: http://www.activeandhealthy.nsw.gov. au.

19. Justine M, Hamid T, Mohan V, Jagannathan M. Effects of multicomponent exercise training on physical functioning among institutionalized elderly. International Scholarly Research Network Rehabilitation 2012; 1 (2012): 1- 7.

20. Panton L, Loney B. Exercise for older adult. $1^{\text {st }}$ ed. Florida: Florida State University, 2015; 3- 10, 84- 95.

21. Thiamwong L, Suwanno J. Effects of simple balance training on balance performance and fear of falling in rural older adults. International Journal of Gerontology 2014; 8 (2014): 143- 6 .

22. Sá AC, Bachion MM, Menezes RL. Physical exercises to prevent falls: a clinical trail with institutionalized elderly in the city of Goiânia in Barazil. CienSaude Colet 2012; 17 (8): 2117- 27.

23. Akron O. Strength and balance training: a program for older adults. The Journal on Active Aging 2003; 9 (10): 28- 32

24. Tomicki C, Zanini S, Cecchin L, Benedetti T, Portella M, Leguisamo C. Effect of physical exercise program on the balance and risk of falls of institutionalized elderly persons: a randomized clinical trail. Rev. Bras. Geriatr. Gerontol. Rio De Janeiro 2016; 19 (3): 473- 82.

25. Thiamwong L, Suwanno J. Effects of simple balance training on balance performance and fear of falling in rural older adults. International Journal of Gerontology 2014; 8 (2014): 143- 6 .

26. Tinetti M, Williams T, Mayewski R. Fall risk index for elderly patients based on number of chronic disabilities: Tinetti balance assessment tool. Am J Med 1986; 80 (11): 42934.

27. Sherrington C, Tiedemann A. Physiotherapy in the prevention of falls in older people. Journal of Physiotherapy 2015; 61 (2015): 5460.

28. Cho S, An D. Effects of a fall prevention exercise program on muscle strength and balance of the old-old elderly. J. Phys. Sci. 2014; 26 (11): 1771- 4.

29. Irez G. The effects of different exercises on balance, fear and risk of falling among adults aged 65 and over. Anthropologist 2014; 18 (1): 129- 34

30. Chang M, Huang Y, Jung $H$. The effectiveness of the exercise education program on fall prevention of the 
community dwelling elderly: a preliminary study. Hong Kong Journal of Occupational Therapy 2011; 2011 (21): 56- 63 .

31. Howe T, Rochester L, Neil F, Skelton D, Ballinger C. Exercise for improving balance in older people. Cochrance Database Syst. Rev. 2011; 9 (11): 26- 31.

32. Cameron I, Gillespie L, Robertson M, Murray G, Hill K, Cumming R, Kerse $\mathrm{N}$. Interventions for preventing falls in older people in care facilities and hospitals. Cochrance Database Syst. Rev. 2012; 12 (12): 29- 35.

33. Kendrick D, Kumar A, Carpenter H, Zijlstra GA, Skelton D, Cook J, Stevens Z, Belcher CM, Haworth D, Gawler S, Gage H, Masud T, Bowling A, Pearl M, Morris R, Lliffe S, Delbaere K. Exercise for reducing fear of falling in older people living in the community. Cochrance Database Syst. Rev. 2014; 28 (11): 35- 9.
34. Gillespie L, Robertson M, Gillespie W, Sherrington C, Gates S, Clemson $\mathrm{L}$, Lamb S. Interventions for preventing falls in older people living in the community. Cochrance Database Syst. Rev. 2012; 12 (9): 4651.

35. Suzuki T, Kim H, Yoshida H, Ishizaki T. Randomized controlled trail of exercise intervention for prevention of falls in community dwelling elderly Japanese women. J Bone Miner Metab 2004; 22 (6): 602- 11.

36. Guo J, Tsai Y, Liao J, Tu H, Huang C. Interventions to reduce the number of falls among older adults with / without cognitive impairment: an exploratory meta-analysis. Int $\mathbf{J}$ Geriatr Psychiatry 2014; 29 (7): 24- 9. 